\title{
Anatomical and histochemical bark changes due to growth of Tillandsia recurvata (ball moss)
}

Botanical Sciences 94 (3): 551-562, 2016

DOI: 10.17129/botsci.531

\author{
Silvia Aguilar-RodríGuez ${ }^{1,4}$, Teresa Terrazas², María Elena Huidobro-Sa- \\ LAS $^{3}$ AND ERnesto AguirRe-LeÓN ${ }^{3}$
}

${ }^{1}$ Unidad de Morfología y Función, Laboratorio de Botánica, FES Iztacala, Universidad Nacional Autónoma de México, Estado de Mexico, Mexico.

${ }^{2}$ Instituto de Biología, Universidad Nacional Autónoma de México, Mexico, D.F., Mexico.

${ }^{3}$ Herbario IZTA. Universidad Nacional Autónoma de México, Estado de Mexico, Mexico.

${ }^{4}$ FES Iztacala, Universidad Nacional Autónoma de México, Mexico. Mexico.

${ }^{4}$ Corresponding autor: siagro@ campus.iztacala.unam.mx

\section{Abstract}

Excessive growth of Tillandsia recurvata (ball moss) may impact host architecture and survival. For a better understanding of this effect, an anatomical and histochemical bark assessment was carried out in four host species. The PCoA (principal coordinate analysis) showed that the presence of tannins, lignin and a lipidic substance as well as different periderm characteristics (number of phellem and phelloderm layers) and bark thickness are the most important bark traits detected as a response to epiphyte growth. The establishment of ball moss can occur on rough and smooth barks; however barks differed in their anatomy and response to the establishment of ball moss. For example, the development of a wounded periderm and the deposition of condensed tannins in the bark of Prosopis laevigata and Parkinsonia praecox distinguished them from the other two hosts studied. In contrast, neither anatomical nor histochemical changes in Crataegus mexicana or Pittocaulon praecox were obvious due to the intrinsic presence of chemical and structural barriers, respectively. In the studied host species, a matrix of a lipidic substance was formed in the bark-root interface, whether this substance is produced by the roots of the ball moss or the hosts, needs further research. Bark responses to ball moss can be divided into mechanical and chemical and both are strategies related to the taxonomic group of the studied host species.

Keywords: Bark changes, Crataegus mexicana, epiphyte, host, Parkinsonia praecox, Pittocaulon praecox, Prosopis laevigata, semiarid regions.

\section{Cambios anatómicos e histoquímicos en la corteza de árboles debido al crecimien- to de Tillandsia recurvata (Musgo bola) Resumen}

El crecimiento excesivo de Tillandsia recurvata (Musgo bola) modifica la arquitectura y la supervivencia de los forófitos. Para una mejor comprensión de este efecto, se estudió la anatomía e histoquímica de la corteza en cuatro especies de árboles hospederos. El análisis de coordenadas principales (PCoA) mostró que la presencia de taninos, lignina y una sustancia lipídica, así como diferentes características de la peridermis (número de capas del felema y felodermis) y el grosor de la corteza son las respuestas más importantes de la corteza ante el establecimiento de la epífita. El Musgo bola puede establecerse en cortezas rugosas y lisas; sin embargo, las cortezas difieren en su anatomía y en su respuesta al establecimiento de la epífita. Por ejemplo, las cortezas de Prosopis laevigata y Parkinsonia praecox se distinguen por el desarrollo de un súber de reacción y la expresión de taninos condensados. En contraste, ningún cambio anatómico o histoquímico se evidenció en Crataegus mexicana y Pittocaulon praecox, debido a la presencia intrínseca de barreras químicas y estructurales, respectivamente. En las especies estudiadas se formó una matriz de naturaleza lipídica en la interface corteza-raíz; sin embargo, se desconoce si la raíz del Musgo bola o los hospederos la producen, pregunta que requiere de trabajo adicional. La respuesta de la corteza al Musgo bola puede dividirse en mecánica o química y ambas son estrategias relacionadas al grupo taxonómico de las especies hospederas estudiadas.

Palabras clave: Cambios de la corteza, Crataegus mexicana, epífitas, huésped, Parkinsonia praecox, Pittocaulon praecox, Prosopis laevigata, regiones semiáridas. 
illandsia recurvata L. (ball moss) is a common epiphyte in America, distributed from the southeastern United States to southern Argentina (Smith \& Downs 1977). Ball moss grows on many forest species. In recent years, Guevara-Escobar et al. (2011) suggested that forest disturbance and climate change may increase the number of individuals on different hosts. Excessive growth of T. recurvata can cause injuries to the hosts (Montaña et al. 1997, Soria et al. 2014) or reduce host growth (Flores-Palacios et al. 2014), thus modifying reproductive effort (Castellanos-Vargas et al. 2009). Other studies on epiphytic flora, report higher abundances of Tillandsia species in open or perturbed sites (Aguirre et al. 2010, Poltz \& Zotz 2011). In semiarid areas, this particular interaction has received less attention (García-Suárez et al. 2003, Bernal et al. 2005, Escutia-Sánchez 2009).

The interaction between Tillandsia spp. and their hosts is a well-known phenomenon (Benzing 1990, Wagner et al. 2015); however, bark structural characteristics at the bark-root interface have been poorly documented. For example, detailed bark structural changes associated with $T$. recurvata establishment, i.e. a wounded periderm, were described in Parkinsonia praecox and Prosopis laevigata (Páez-Gerardo et al. 2005, Aguilar-Rodríguez et al. 2007). However, the nature of the chemical compounds present in this bark-root interface is unknown. Our hypotheses were that structural and chemical changes similar to those produced by damage can be equally documented in the bark of different hosts when ball moss is present. The aims of this study were to describe bark morpho-anatomical and histochemical changes caused by the interaction between ball moss and their hosts.

\section{Material and methods}

Four host species (Crataegus mexicana, Parkinsonia praecox, Prosopis laevigata, and Pittocaulon praecox, Table 1, Figure 1) were selected for this study because of their contrasting bark surfaces and because in recent years, abundance of Tillandsia recurvata seems to have increase in these species (Ernesto Aguirre-León, unpublishing data). Sixty nine branches were collected in total during dry season. Three branches were collected per tree, in two to 12 trees per host species (Table 1, Figure 1D-F). The three branches had ca. $3 \mathrm{~cm}$ in diameter and were sectioned with a saw in cylindrical samples $(2 \times 3 \mathrm{~cm})$, free from epiphytes or hosting epiphytes. We ensured that epiphyte roots remained fixed to the bark and in those branch regions without epiphytes, areas free of scars and thorns were selected to avoid any effect they may have. All segments were fixed in formalin-alcohol-glacial acetic acid (0.5:9.0:0.5, Ruzin 1999) for $48 \mathrm{~h}$. Anatomy. Transverse and longitudinal sections (20-25 $\mu \mathrm{m}$ thick) were cut using a sliding mi-

Table 1. Species, localities and vegetation types where samples were collected. All collection numbers correspond to S. Aguilar-Rodríguez and were deposited in the herbarium FESI. The collection number corresponds to each individual sampled.

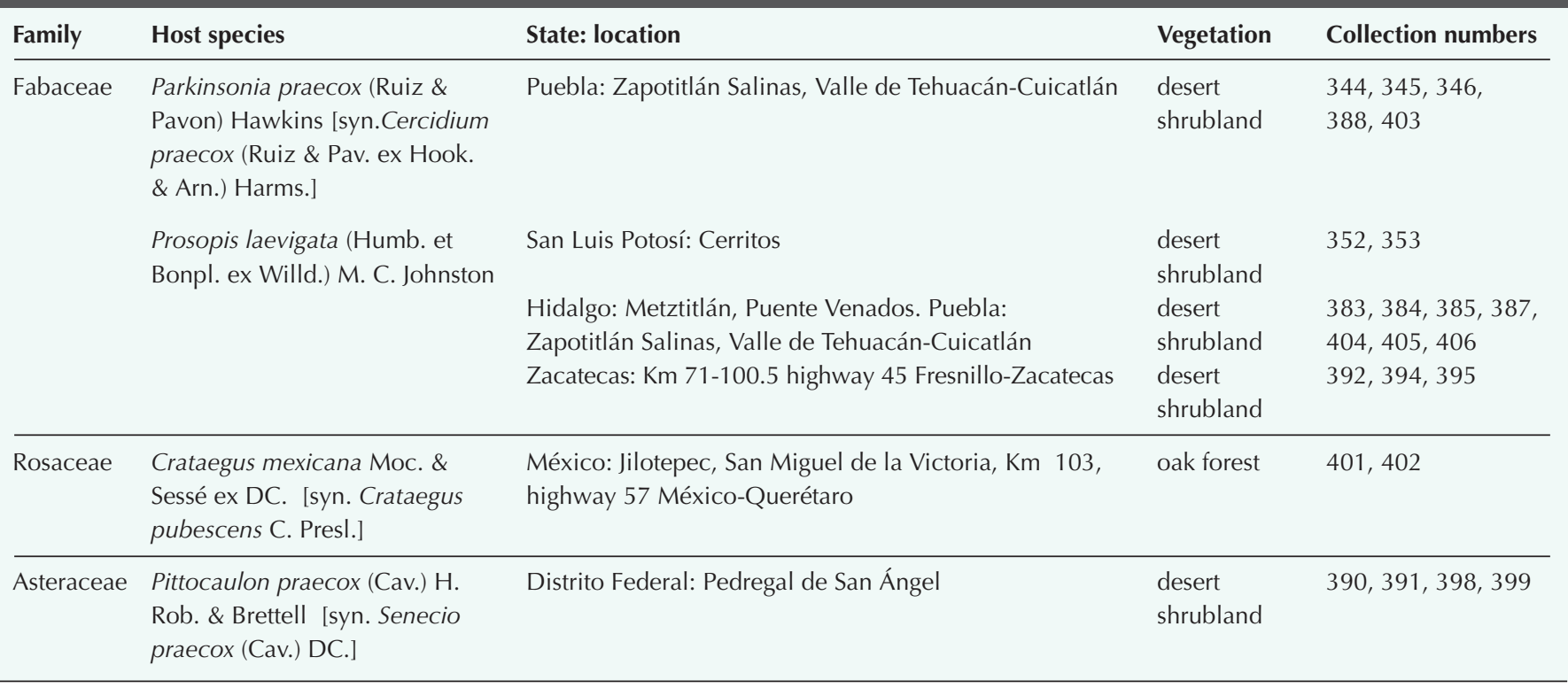




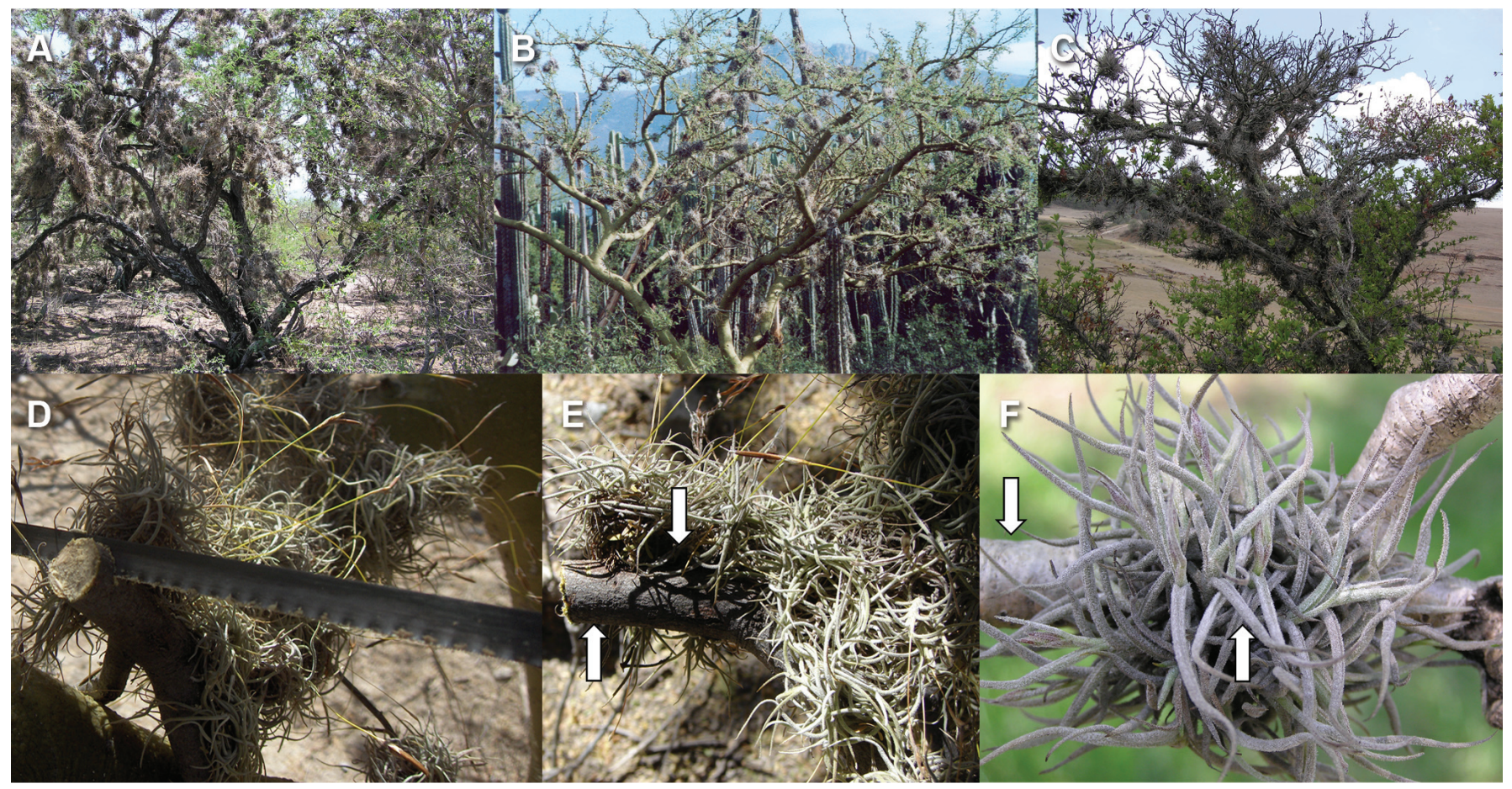

Figure 1. Ball moss growing on different hosts. A) Prosopis laevigata. B) Parkinsonia praecox. C) Crataegus mexicana. D) Detail of branch cut, Parkinsonia praecox. E) Detail of Prosopis laevigata branch with and without epiphyte. F) Detail of Pittocaulon praecox branch with and without epiphyte. Arrows indicate the place where branch with and without ball moss were sectioned for anatomical studies.

crotome, including bark and wood. For anatomical descriptions, selected sections were stained with safranin-fast green and mounted with synthetic resin. In the case of Pittocaulon praecox, samples were dehydrated in a Leica automatic TP1020 changer and embedded in paraffin, sections $15 \mu \mathrm{m}$ thick were cut with a rotary microtome, stained with safranin-fast green (Ruzin 1999), and mounted with synthetic resin. In order to maintain the epicuticular wax layer of $P$. praecox, some sections were stained with safranin-crystal violet and mounted in glycerin jelly. Other sections were used to perform the histochemical tests. The anatomical descriptions were made following the terminology of Trockenbrodt (1990) and the histochemical techniques were performed according to Ruzin (1999). Sudan IV was used to detect lipids, vainillin was used to test for condensed tannins (catechins/proanthocyanids, Broadhurst \& Jones 1978), ferrous sulfate to test for hydrolysable tannins, tannic acid-ferric chloride to test for calcium pectate, and Lugol's solution to test for starch. To detect lignin, sections were treated with phloroglucinol and hydrochloric acid. The intensity of the reactions was recorded according to a ranked scale (0: negative, 1: faint, 2 : moderate, 3 : intense).

Statistical analysis. Fifteen variables (Tables 3 ) were analyzed with a principal coordinate analysis (PCoA), because we had a combination of 14 categorical variables and one continuous one. PCoA is an exploratory technique in which the inertia is analogous to the concept of variance in principal component analysis and it is proportional to the chi-square. For each condition with and without ball-moss, the 23 hosts studied were included in the analysis. We observe for those variables that better contributed to explain the variance associated with ball moss presence. The analysis was performed using SAS statistical program (Release 9.2 SAS Institute Inc., Cary, NC).

\section{Results}

Traces of damaged bark tissues in the bark-root interface in Parkinsonia praecox, Prosopis laevigata, Crataegus mexicana, and Pittocaulon praecox were found, when compared to unoccupied bark. These findings were at the histochemical and anatomical level (Tables 2, 3, Figures 2-4). 
Table 2. Bark characteristics of Parkinsonia praecox (from Páez-Gerardo et al., 2005), Prosopis laevigata (from Aguilar-Rodríguez et al., 2007), Crataegus mexicana, and Pittocaulon praecox. STE-CC = sieve tube element-companion cell, PA = parenchyma.

\begin{tabular}{|c|c|c|c|c|c|}
\hline & & Parkinsonia praecox & Prosopis laevigata & Crataegus mexicana & Pittocaulon praecox \\
\hline \multirow{3}{*}{$\begin{array}{l}\text { Morpho- } \\
\text { logical } \\
\text { characters }\end{array}$} & Color & light green & dark gray-brown & reddish-gray & green-gray \\
\hline & Texture & $\begin{array}{l}\text { rough to weakly ridged } \\
\text { with thorn scars }\end{array}$ & $\begin{array}{l}\text { rough, having } \\
\text { quadrangular plates, } \\
\text { thorn scars abundant }\end{array}$ & $\begin{array}{l}\text { rough to weakly } \\
\text { fissured with thorn } \\
\text { scars }\end{array}$ & $\begin{array}{l}\text { smooth with some } \\
\text { horizontal scars }\end{array}$ \\
\hline & Thickness (mm) & 1.5 & $1.5-1.7$ & $0.8-0.9$ & $2.5-3.5$ \\
\hline \multirow[t]{3}{*}{ Outer bark } & Periderm phellem & $\begin{array}{l}\text { papillose outer cells } \\
\text { covered by a wax-layer, } \\
\text { multiple epidermis } \\
\text { (Figure } 2 A, B \text { ) }\end{array}$ & $\begin{array}{l}>15 \text { cell strata with } \\
\text { thicker periclinal cell } \\
\text { walls }\end{array}$ & $\begin{array}{l}3-5 \text { cell strata with } \\
\text { thicker periclinal walls } \\
\text { (Figure } 3 \mathrm{~A}, \mathrm{~B} \text { ), and } \\
\text { orange contents } \\
\text { (tanniferous deposits). }\end{array}$ & $\begin{array}{l}>20 \text { cell strata, strongly } \\
\text { suberized towards the } \\
\text { surface (Figure } 3 \mathrm{G} \text { ). }\end{array}$ \\
\hline & phelloderm & ---- & $\begin{array}{l}5 \text { or more strata, } \\
\text { thin-walled cells }\end{array}$ & $\begin{array}{l}\text { A single stratum, } \\
\text { thin-walled cells }\end{array}$ & $\begin{array}{l}3 \text { layers, thin-walled } \\
\text { cells }\end{array}$ \\
\hline & $\begin{array}{l}\text { Collapsed } \\
\text { phloem }\end{array}$ & $\begin{array}{l}\text { PA expanding and } \\
\text { forming } 1-2 \text { layers } \\
\text { tangential bands }\end{array}$ & $\begin{array}{l}\text { discontinuous } \\
\text { sclerenchyma bands }\end{array}$ & $\begin{array}{l}\text { PA larger with dark-stained } \\
\text { contents, separated by } \\
\text { sclerenchyma bands } \\
\text { towards cortex }\end{array}$ & $\begin{array}{l}\text { STE-CC and PA } \\
\text { collapsed forming } \\
\text { discontinuous patches }\end{array}$ \\
\hline \multirow[t]{2}{*}{ Inner bark } & Phloem rays & funnel-shaped & funnel-shaped & narrow (Figure 3A). & funnel-shaped \\
\hline & $\begin{array}{l}\text { Non-collapsed } \\
\text { phloem }\end{array}$ & $\begin{array}{l}\text { STE-CC between } \\
\text { PA bands }\end{array}$ & $\begin{array}{l}\text { STE-CC in radial } \\
\text { rows }\end{array}$ & $\begin{array}{l}\text { STE-CC and PA in } \\
\text { tangential bands }\end{array}$ & $\begin{array}{l}\text { STE-CC in clusters } \\
\text { mixed with PA }\end{array}$ \\
\hline
\end{tabular}

Table 3. Comparison of the histochemical observations and anatomical characteristics in the bark of the four host species. WB: without ball moss, BM: with ball moss. Histochemical reactions. $0=$ negative, $1=$ positive faint, $2=$ positive moderate, $3=$ positive intense. Anatomical characters. Texture: $0=$ smooth, 1 = weakly fissure, $2=$ weakly ridged, $3=$ modified. Rhytidome: $0=$ absent, $1=$ present. Number of phellem layers: $0=$ absent, $1=<10$ strata, $2= \pm 15$ strata, $3=>20$ strata. Phellem cells: $0=$ absent, $1=$ no collapsed, $2=$ collapsed. Number of phelloderm layers: $0=$ absent, $1=1-3$ strata, $2=\geq 5$ strata. Crystals in the outer cortex: $0=$ absent, $1=$ present. Wounded periderm: $0=$ absent, $1=$ present. Lipidic substance: 0 = absent, 1 = present.

\begin{tabular}{cccccccc} 
Parkinsonia & praecox & Prosopis & laevigata & Crataegus & mexicana & Pithocaulon & praecox \\
WB & BM & WB & BMPE & WB & BM & WB & BM \\
\hline
\end{tabular}

\section{Histochemical reactions}

Lipids

Condensed tannins

Hydrolyzable tannins

Calcium pectates

Lignin

Starch

$\begin{array}{lll}2 & & 1 \\ 0 & 1 & 0 \\ 0 & 1 & 0 \\ 1 & 0 & 1 \\ 2 & 0 & 2 \\ 1 & 0 & 2\end{array}$

\section{Anatomical characters}

Bark thickness (mm)

Texture

Rhytidome

Number of phellem

number of layers

Phellem cells

Number of

phelloderm layers

Crystals in the

outer cortex

Wounded periderm

$\begin{array}{ccc}0.82-0.97 & 1.25-1.33 & 1 . \\ 2 & 3 \\ 0 & 0 \\ 0 & 2 \\ 0 & 1 \\ 0 & 0 \\ 1 & 1 \\ 0 & 1\end{array}$

1
0
0
1
2
2 $\quad$ o

1
3
1
0
0
2

\begin{tabular}{llll}
2 & 2 & 2 & 2 \\
1 & 1 & 0 & 0 \\
3 & 3 & 0 & 0 \\
3 & 3 & 1 & 1 \\
2 & 2 & 0 & 0 \\
2 & 2 & 1 & 0 \\
\hline
\end{tabular}

Bark-epiphyte interface

Lipidic substance

0

1

$\begin{array}{cr}1.58-2.10 & 1.5 \\ 1 & \\ 1 & \\ 2 & \\ 1 & \\ 2 & \\ 1 & \\ 0 & \end{array}$

$\begin{array}{ll}59-2.11 & 0.85 \\ 3 & \\ 0 & \\ 2 & \\ 2 \\ 0 \\ 1 \\ 1\end{array}$

\begin{tabular}{cccc}
$.85-0.90$ & $0.85-0.90$ & $2.8-3.2$ & $2.8-3.3$ \\
1 & 3 & 0 & 3 \\
0 & 0 & 0 & 0 \\
1 & 1 & 3 & 3 \\
1 & 2 & 1 & 2 \\
1 & 1 & 1 & 1 \\
1 & 1 & 0 & 0 \\
0 & 0 & 0 & 0 \\
\hline
\end{tabular}

0

1

0

1

0

1 


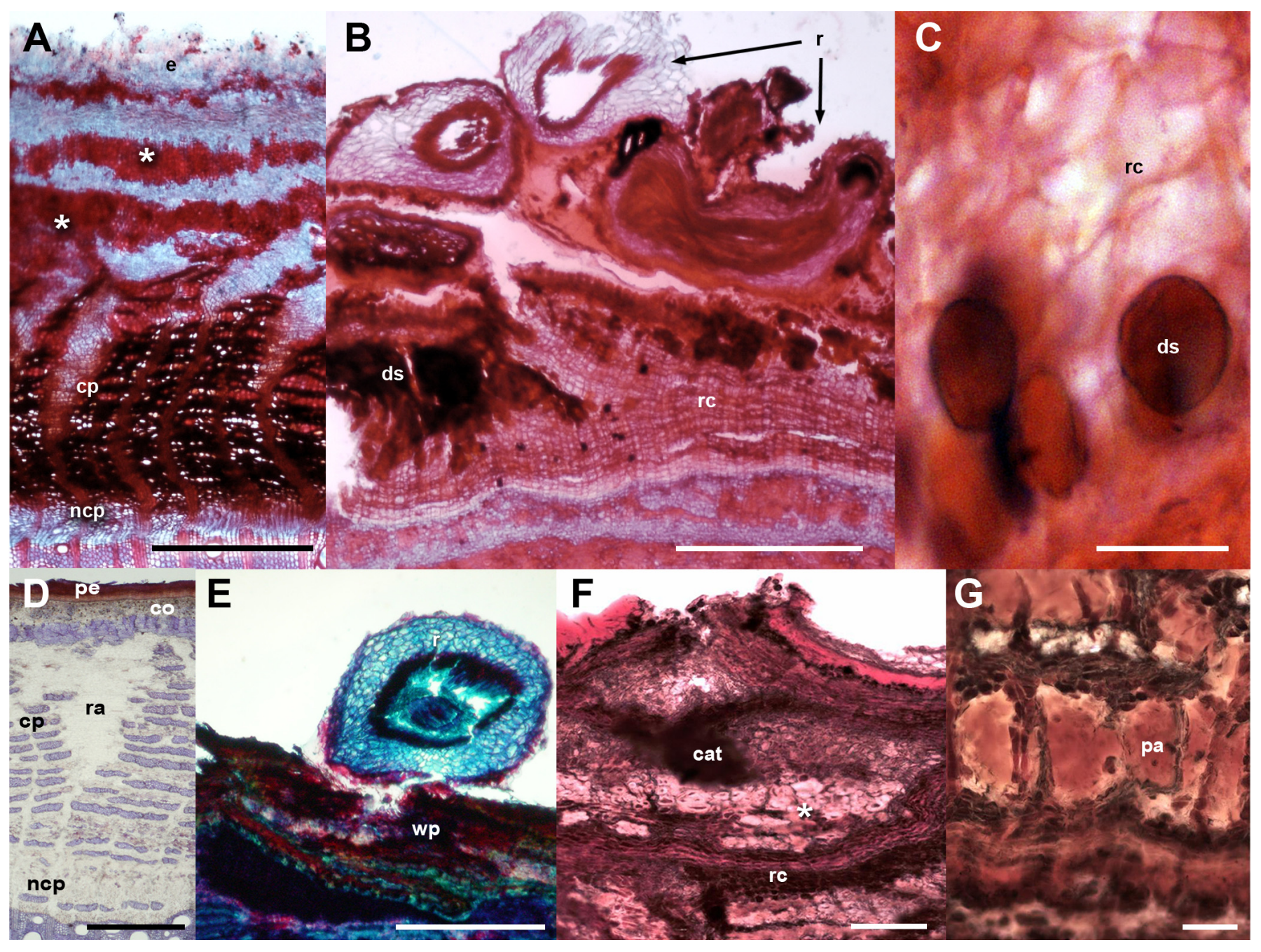

Figure 2. Fabaceae barks with and without ball moss. A-C. Parkinsonia praecox. A) Bark free of ball moss, transverse-section. B) Attached roots of ball moss. C) Positive suberin reaction in radially expanded cells. D-G. Prosopis laevigata. D) Bark free of ball moss, transversesection. E) Root of ball moss attached and proliferation of multiple cell layers. F) Positive reaction to condensed tannins associated to reaction bark. G) Detail of parenchyma cells with condensed tannins. Scale bar: A = 250 $\mu \mathrm{m}, \mathrm{B}, \mathrm{C}, \mathrm{F}=500 \mu \mathrm{m}, \mathrm{D}, \mathrm{E}=50 \mu \mathrm{m}, \mathrm{G}=100 \mu \mathrm{m}$. Asterisk $=$ sclerenchyma bands, cat $=$ condensed tannins, $c o=$ cortex, $\mathrm{cp}=$ collapsed phloem, $\mathrm{ds}=$ dark-staining deposits, $\mathrm{e}=$ epidermis + wax, $\mathrm{ncp}=$ noncollapsed phloem, $\mathrm{pa}=$ parenchyma, $\mathrm{pe}=$ periderm, $\mathrm{r}=$ root, $\mathrm{ra}=$ ray, $\mathrm{wp}=$ wounded periderm.

Bark anatomical changes in the bark-root interface. In contact with the roots of Tillandsia recurvata, Parkinsonia praecox showed a wounded periderm, 300-400 $\mu \mathrm{m}$ thick (Figure 2B), developed by the most superficial cortical cells, underneath the epidermis (Figure 2B). The wounded periderm had radially expanded cells with thin walls and wide lumina, occluded with dark-staining deposits (Figure 2C). Neither the epidermal papillose cells nor the epicuticular wax layer was observed where the ball moss roots were attached (Figure 2B). The Sudan IV reaction was positive for lipids (Table 3). In Prosopis laevigata the peridermal cells lost their radial organization and a wounded periderm was developed by the cortical cells (Figure 2E). Some collapsed cells between the wounded periderm and the original periderm were observed (Figure 2F). In the collapsed phloem, there were groups of cells with abundant intercellular spaces and dark-staining deposits occluding their cellular lumen (Figure 2G). In some cases damage extended deeper, modifying secondary xylem. In Crataegus mexicana, few phellem layers lost their radial arrangement, but no other structural change was distinguished (Figure 3C). Finally, in Pittocaulon praecox no structural changes were observed (Figure 3H). The roots of ball moss were confined to the surface of the phellem. However, in some cases, roots penetrated into phellem layers, separating them radially (Figure $3 \mathrm{H}$ ). 

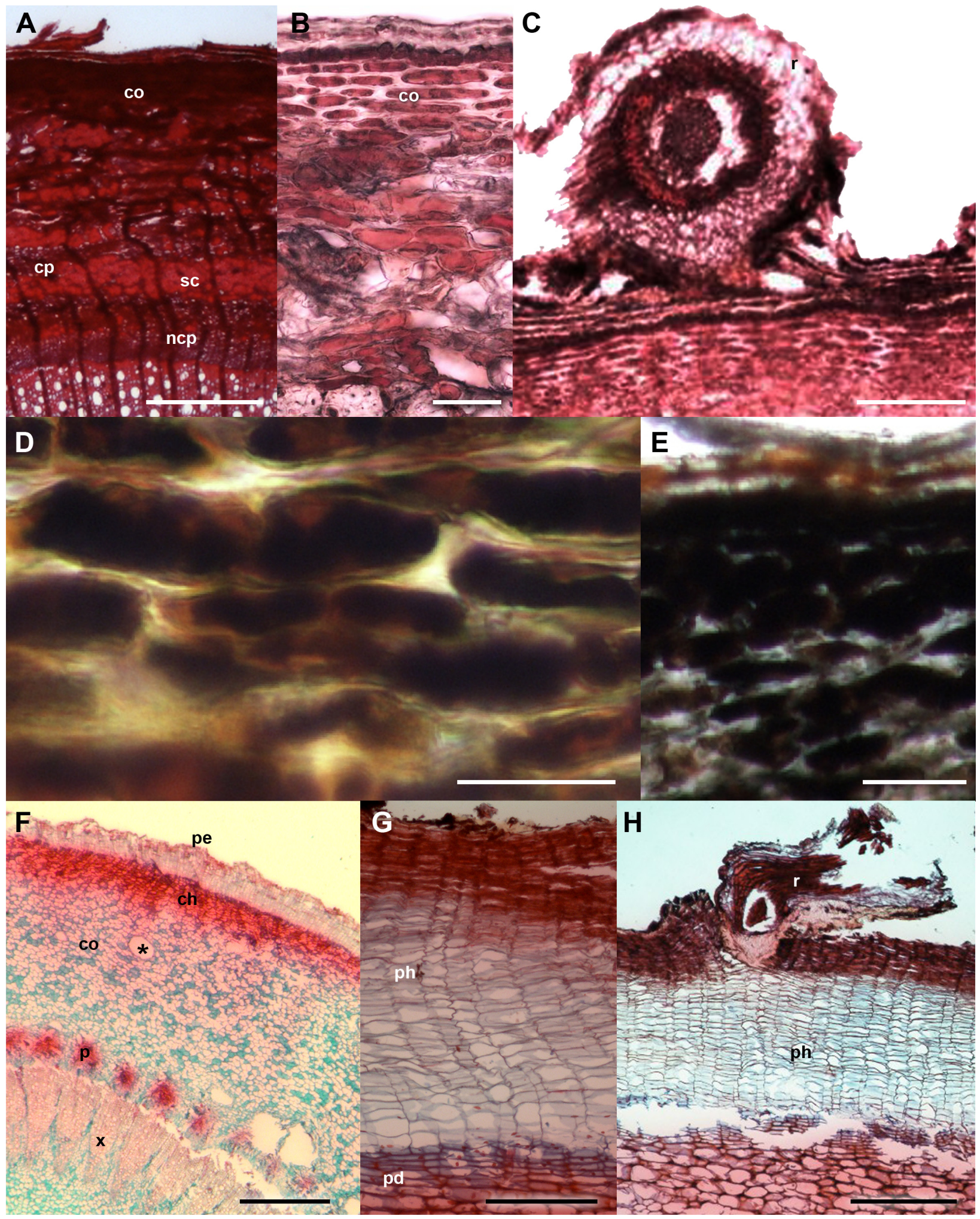

Figure 3. Crataegus mexicana and Pittocaulon praecox barks with and without ball moss. A-E. C. mexicana. A) Bark free of ball moss, cross-section. B) Periderm and thick-walled cortical cells. C) Bark-root interface. D) Positive reaction of calcium pectates in parenchyma cells. E) Positive reaction to starch grains. F-H. P. praecox. F) General view. G) Periderm with several layer of phellem. H) Detail of the bark-root interface. Scale bar: A $=300 \mu \mathrm{m}, \mathrm{B}, \mathrm{D}=50 \mu \mathrm{m}, \mathrm{C}, \mathrm{G}=150 \mu \mathrm{m}, \mathrm{E}=100 \mu \mathrm{m}, \mathrm{F}=500 \mu \mathrm{m}, \mathrm{H}=400 \mu \mathrm{m}$. asterisk = mucilage channel, $\mathrm{ch}=$ collenchyma, $\mathrm{co}=$ cortex, $\mathrm{cp}=$ collapsed phloem, $\mathrm{ncp}=$ noncollapsed phloem, $\mathrm{pd}=$ phelloderm, $\mathrm{pe}=$ periderm $, \mathrm{ph}=\mathrm{phellem}, \mathrm{r}=$ root, $\mathrm{sc}=$ sclerenchyma . 
Table 4. Singular values, principal inertia, Chi-square, and percentage of variance of coordinate analysis for bark changes in the bark-ball moss interface.

\begin{tabular}{ccccc} 
Dimension & Singular value & Principal inertia & Chi-square & Percentage \\
\hline 1 & 0.523 & 0.273 & 200.174 & 47.74 \\
2 & 0.338 & 0.115 & 83.883 & 20.01 \\
3 & 0.278 & 0.077 & 56.561 & 13.49 \\
4 & 0.254 & 0.064 & 47.183 & 11.25 \\
\hline
\end{tabular}

Statistical analysis. The multivariate analysis showed that the first two dimensions explained $67.75 \%$ of the total inertia (variance, Table 4). More than $47 \%$ of the total variance was explained by the first dimension (Table 4), therefore only two dimensions were selected (Figure 5). The plot shows that particular host species, with and without ball moss, are separated according to the histo-chemical and anatomical characteristics. Both, Parkinsonia praecox and Prosopis laevigata individuals with and without ball moss were clearly separated across the first two di-

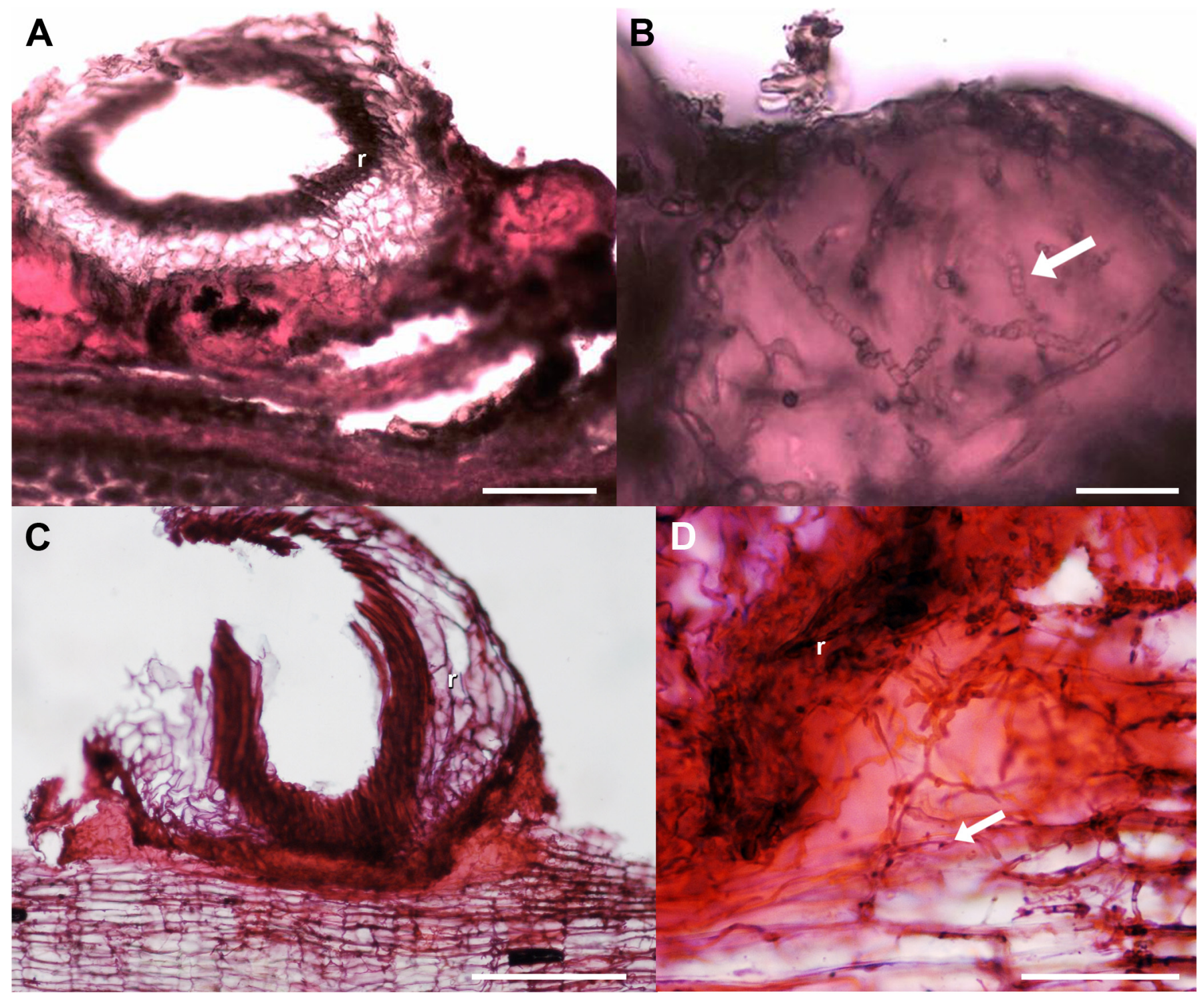

Figure 4. Lipidic substance developed in the bark-root interface, transverse sections. A, B) Crataegus mexicana. C, D) Pittocaulon praecox. Scale bar: A, B = $100 \mu \mathrm{m}, \mathrm{C}=200 \mu \mathrm{m}, \mathrm{D}=50 \mu \mathrm{m}$. Arrow $=$ hyphae, $\mathrm{r}=$ root. 
Table 5. Partial contribution to inertia for the hosts with and without ball moss. In bold those characters that showed the highest values for each dimension.

\begin{tabular}{lcc} 
Character & Dimension 1 & Dimension 2 \\
\hline Lipids (sudan IV) & 0.0143 & 0.0001 \\
Condensed tannins (vainillin) & 0.2358 & 0.0216 \\
Hydrolyzable tannins (ferrous sulfate) & 0.0229 & $\mathbf{0 . 2 8 8 2}$ \\
Calcium pectates (tannic acid-ferric chloride) & 0.0901 & 0.0682 \\
Lignin (phloruglucinol and HCl) & $\mathbf{0 . 1 9 7 7}$ & 0.1621 \\
Starch (lugol) & 0.0023 & 0.0158 \\
Bark thickness (mm) & 0.0031 & $\mathbf{0 . 1 5 0 9}$ \\
Texture & 0.0503 & 0.0035 \\
Rhytidome & 0.0857 & 0.0103 \\
Number of phellem layers & 0.0001 & $\mathbf{0 . 1 1 3 6}$ \\
Number of phelloderm layers & $\mathbf{0 . 1 0 0 4}$ & 0.0992 \\
Crystal in the outer cortex & 0.0003 & 0.0361 \\
Phellem cells & 0.0169 & 0.0223 \\
Wounded periderm & 0.0744 & 0.0069 \\
Lipidic substance & $\mathbf{0 . 1 0 5 7}$ & 0.0010
\end{tabular}

Figure 5. Ordination plot grouping the four host species studied according the characters considered (those with the highest values of partial inertia, Table 5); based on 69 bark samples. Full symbols represent hosts individuals with ball moss and empty symbols represent those without ball moss; symbol thickness represents the number of host individuals: slender $=1$, thick $=2$, thicker $=3$. Triangles $=$ Crataegus mexicana, Squares = Parkinsonia praecox, Diamonds = Pittocaulon praecox Circles = Prosopis laevigata . Abbreviations: condtann = Condensed tannins, lipidicsubs = Lipidic substance, nuphelle $=$ Number of phellem layers, thick $=$ Bark thickness, hydrotann $=$ Hydrolyzable tannins, nuphello = Number of phelloderm layers, lignin $=$ Lignin.

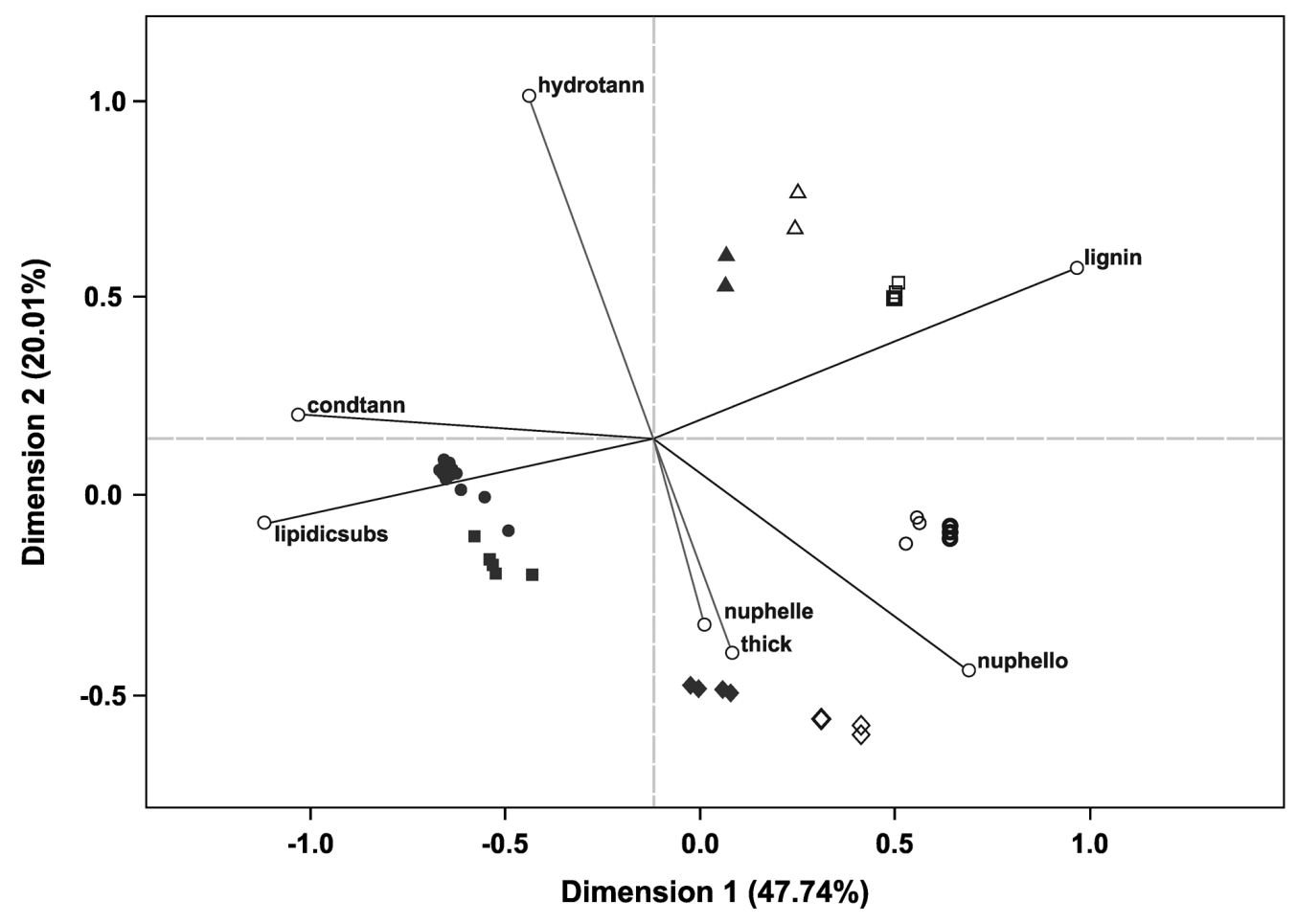

mensions. In contrast, Crataegus mexicana and Pittocaulon praecox individuals, with and without the epiphyte are barely separated from each other (Figure 5). Groups of Parkinsonia praecox and Prosopis laevigata were distinctly divided because of the evident structural and chemical changes possibly caused by the presence of ball moss. Among the variables reflecting these differences are occurrence of condensed and hydrolyzable tannins, reduction of lignin, presence of a lipidic substance, increase in bark thickness, and in number of phelloderm and phellem cell layers (Table 5, Figure 5). The variables wounded periderm, collapsed phellem cells and texture were weakly related to the presence of ball moss (Table 5). Other characters, such as calcium 
pectates, rhytidome, and crystals in the outer cortex are some of the host specific traits that were not modified by the presence of ball moss.

\section{Discussion}

The most important differences of the bark-root interface to the bark alone in all studied hosts were the occurrence of a lipidic substance (Table 3, Figure 4) and some structural or chemical modifications. Structural and chemical differences were evident in the legumes bark (Figure 5), in other cases, a chemical or structural (anatomical) protection was intrinsic to each host species, and these differences were observed in the ordination.

Bark morphology. It is thought that rough surfaces on branches favor germination and anchorage of ball moss seedlings because smooth surfaces retain less water and nutrients from rain (Catling \& Lefkovitch 1989, García-Suárez et al. 2003). However, our observations agreed with those of Benzing (1990) and Wagner et al. (2015), who state that surface does not always has a decisive effect on epiphyte anchoring. The studied species, independently of their rough (Crataegus mexicana, Parkinsonia praecox and Prosopis laevigata) or smooth (Pittocaulon praecox) barks, hosted an elevated number of ball moss individuals. Moreover, Escutia-Sánchez (2009) mentioned that Pittocaulon praecox can also host an elevated number of ball moss as a result of disturbance. Some authors have noticed that due to global warming, populations of Tillandsia recurvata are increasing (Caldiz et al. 1993, Guevara-Escobar et al. 2011). Since no specific relationship exists between bark texture and epiphyte anchoring; we assume that ball moss and other Tillandsia species may be able to interact with many different hosts and expand to other habits effectively as epiphytic weeds (Claver et al. 1983, Caldiz et al. 1993). However, many other factors such as host specificity or habitat filtering may have an effect on anchoring and establishment (Wagner et al. 2015).

Anatomy and chemistry of barks without ball moss. In the host species, some differences in bark structure are related to their taxonomic group. Branches of the four host species had non-collapsed phloem, collapsed phloem, and cortex. A periderm was observed in three host species, while the other one, Prosopis laevigata develops a rhytidome. Instead of a typical periderm, Parkinsonia praecox has a multiple epidermis covered by a thick epicuticular wax layer. Both, $P$. laevigata and P. praecox (both Fabaceae) have abundant prismatic crystals, dilated rays, and sclerenchyma bands (Roth 1981). Anatomical differences between these legumes (Table 2) included the absence of sclerenchyma in the collapsed phloem and a multiple epidermis (sensu Roth 1981) in P. praecox, and a typical periderm, rhytidome and sclereids in the collapsed phloem in P. laevigata. Independently of the strong differences in outer bark, both legumes had similar anatomical and histochemical changes as a consequence of the presence of ball moss.

Pittocaulon praecox (Asteraceae) and Crateagus mexicana (Rosaceae) barks also showed features typical of their taxonomic group. Pittocaulon praecox had a wide phellem (>20 layers thick), a wide cortex with numerous canals, and scanty secondary phloem. The absence of sclerenchyma in its cortex and the presence of collenchyma beneath the periderm agreed with the observations of Olson (2005) for P. praecox. Parenchymatous barks without sclerenchyma are interpreted as adaptations for water accumulation (Roth 1981, Olson 2005). Crataegus mexicana shares with other Maloideae the presence of phloem parenchyma in bands, wavy phloem rays, thicker periclinal walls in phellem, and tanniniferous deposits (Donghua \& Xinzeng 1993).

Chemical compounds such as starch grains in cortical cells and phloem rays, lignin in fibers, and suberin in phellem cells, were present in the four host species studied. A strong reaction to hydrolysable and condensed tannins and calcium pectates in the phellem and in some cortical layers of Crataegus mexicana, indicated that these compounds were synthesized by the plant. Hence, they were interpreted as constitutive (passive) chemical barriers observed even without epiphytes.

Anatomy and chemistry of the barks with ball moss. The establishment of epiphytes caused structural modifications and chemical differentiation among the studied host species. The legumes showed the strongest structural and histochemical changes in response to the interaction with ball 
moss, as confirmed by the multivariate analysis. The anatomical changes in the legumes support previous observations of wounded periderm development that isolates the most internal cortical cells as a response to damage (Páez-Gerardo et al. 2005, Aguilar-Rodríguez et al. 2007). Biggs et al. (1984) recognized the development of a wounded periderm after mechanical damage or the action of a pathogen. This response is well documented in studies where barks are infected by fungi and other microorganisms and is known as compartmentalization (Bramble 1936, Biggs et al. 1984, Best et al. 2004). Our results showed that the strongest modifications beyond bark, reaching the secondary xylem, occurred only in Prosopis laevigata as it has been observed by AguilarRodríguez et al. (2007). This is in agreement with Ruinen (1953) who mentions that epiphytic ferns and orchids can damage hosts by occluding vessels in xylem and by necrosis in vascular and cortical tissues. The dark-staining deposits observed in the injured areas of $P$. laevigata and Parkinsonia praecox corresponded to condensed tannins. These compounds are usually produced as a chemical response to predators (Zucker 1983, Franceschi et al. 2005) as an active response of the plant (Shain 1995). In P. laevigata and P. praecox these condensed tannins likely act to prevent or stop the entry of pathogens. In contrast, lignin was not accumulated at any injured tissue in our study, unlike what has been reported in other studies, in which lignin is present in the injured and infected cortex by pathogens (Biggs \& Peterson 1990).

Pittocaulon praecox and Crataegus mexicana have a single periderm, but differences in their bark organization and chemical compounds seemed to be important to avoid changes under the presence of epiphytes. For example, in Pittocaulon praecox, some of the most superficial phellem layers occasionally break in order to hold the roots of ball moss, and all adjacent cells collapse. The presence of numerous phellem layers probably represents a defense mechanism that inhibits (at first) any possible effect that ball moss could have on the bark. The absence of structural alterations in the bark of $C$. mexicana was related to the chemical compounds of its bark, which are abundant before ball moss establishes. The tannic acid-ferric chloride test for calcium pectates had a positive and intense reaction (Figure 3D) and could be related to a high proportion of amylopectin (Ruzin 1999). It is well-known that calcium pectate is a component of the middle lamina and prevents cellular membrane damage. In addition, an intense reaction also occurred with the ferrous sulfate test, indicating the presence of hydrolysable tannins in this host species, which likely act as a chemical defense of plants (Vivanco et al. 2005). The high natural occurrence of pectin and hydrolysable tannin contents may be responsible for protecting C. mexicana in the presence of epiphytes, since it is a passive chemical barrier in the bark (Shain 1995).

The interface. We found a lipidic substance present in the bark-root interface in all hosts studied. Türkowsky \& López (1983) mentioned a gummy substance in roots of other Tillandsia species which function they interpreted as attaching the roots to the substrate. However, this function has not been tested, to support these conclusions. Moreover, we did not detect a gummy substance; according to our histochemical tests, it is a lipidic substance; however, we do not know if this substance is produced by the Tillandsia roots or the host species barks. Further research is needed to examine whether the roots of ball moss or the hosts are responsible for the occurrence of this lipidic substance that may contribute to their interaction.

We conclude that bark responses to ball moss establishment in the studied host species are strategies related to the taxonomic group they belong to, as it has been demonstrated in conifers reacting against different pests (Franceschi et al. 2005). They can be divided into mechanical and chemical. Both legumes, responded to ball moss developing active mechanical and chemical barriers. In contrast, in Pittocaulon praecox, the phellem represents a passive (intrinsic) mechanical barrier that prevents bark modifications due to the establishment of ball moss and it could be considered as a structural constitutive defense mechanism; whereas in Crataegus mexicana, the passive (intrinsic) barrier is chemical and corresponds to a chemical constitutive defense mechanism. When structural changes exist, these are interpreted as bark injuries. Hence we could suggest that an excessive number of epiphytes may cause branch or even the individual's death in the host species studied. Investigating the anatomical bark characteristics will allow the identification of woody species more susceptible to the establishment of ball moss, this is especially important since ball moss populations are suggested to increase due to climate change. 


\section{Acknowledgments}

We are grateful to "Programa de Apoyo a los Profesores de Carrera para la Formación de Grupos de Investigación" (PAPCA 2007-2008) at FES Iztacala, Universidad Nacional Autónoma de México for funding, to Dalia Grego-Valencia for laboratory assistance, and to Julio César Monteros and Diana Martínez for helping with art work. We thank the anonymous reviewers for their insightful comments.

\section{Literature cited}

Aguilar-Rodríguez S., Terrazas T., Aguirre-León E. and Huidobro-Salas M.E. 2007. Modificaciones en la corteza de Prosopis laevigata por el establecimiento de Tillandsia recurvata. Boletín de la Sociedad Botánica de México 81:27-35.

Aguirre A., Guevara R., García M. and López J.C. 2010. Fate of epiphytes on phorophyte with different architectural characteristics along the perturbation gradient of Sabal mexicana forests in Veracruz, Mexico. Journal of Vegetation Science 21:6-15.

Benzing D.H. 1990. Vascular Epiphytes: General Biology and Related Biota. Cambridge University Press, Cambridge.

Bernal R., Valverde T. and Hernández-Rosas L. 2005. Habitat preference of the epiphyte Tillandsia recurvata (Bromeliaceae) in a semi-desert environment in Central Mexico. Canadian Journal of Botany 83:1238-1247.

Best M.V., Vasanthakumar A. and McManus P.S. 2004. Anatomy of Cranberry stem gall and localization of bacteria in galls. Phytopathology 94:1172-1177.

Biggs A.R. and Peterson A.C. 1990. Effect of chemical applications to peach bark rounds on accumulation of lignin and suberin and susceptibility to Leucostoma persoonii. Phytopathology 80: 861-865.

Biggs A.R., Merrill W. and Davis D.D. 1984. Discussion: Response of bark tissues to injury and infection. Canadian Journal of Forest Research 14:351-356.

Bramble W.C. 1936. Reaction of chestnut bark to invasion by Endothia parasitica. American Journal of Botany 23:89-94.

Broadhurst R.B. and Jones W.T. 1978. Analysis of condensed tannins using vanillin. Journal of the Science of Food and Agriculture 29:788-794.

Caldiz D.O., Beltrano J., Fernández L.V. and Andía I. 1993. Survey of Tillandsia recurvata L.: preference, abundance and its significance for natural forests. Forest Ecology and Management 57:161-168.

Castellanos-Vargas I., Cano-Santana Z. and Hernández-López B. 2009. Efecto de Tillandsia recurvata L. (Bromeliaceae) sobre el éxito reproductivo de Fouquieria splendens Engelm. (Fouquieriaceae). Ciencia Forestal en México 34:199-209.

Catling P.M. and Lefkovitch L.P. 1989. Associations of vascular epiphytes in a Guatemalan cloud forest. Biotropica 21:35-40.

Claver F.K., Alaniz J.R. and Caldíz D.O. 1983. Tillandsia spp.: Epiphytic weeds of tree and bushes. Forest Ecology and Management 6:367-372.

Donghua L. and Xinzeng G. 1993. Comparative anatomy of secondary phloem of ten species of Rosaceae. IAWA Journal 14:289-298.

Escutia-Sánchez J.A. 2009. Heterogeneidad arquitectónica y microclimática en forofitos y distribución espacial de Tillandsia recurvata en un sistema semiárido. Master thesis, Facultad de Ciencias, Universidad Nacional Autónoma de México, Mexico D.F. 42 pp.

Flores-Palacios A., Barbosa-Duchateau C.L., Valencia-Díaz S., Capistrán-Barradas A. and García-Franco J.G. 2014. Direct and indirect effects of Tillandsia recurvata on Prosopis laevigata in the Chihuahua desert scrubland of San Luis Potosi, Mexico. Journal of Arid Environments 104:88-95.

Franceschi V.R., Krokene P., Christiansen E. and Krekling T. 2005. Anatomical and chemical defenses of conifer bark against bark beetles and other pests. New Phytologist 167:353-376.

García-Suárez M.D., Rico-Gray V. and Serrano H. 2003. Distribution and abundance of Tillandsia spp. (Bromeliaceae) in the Zapotitlán Valley, Puebla, México. Plant Ecology 166:207-215.

Guevara-Escobar A., Cervantes-Jiménez M., Suzán-Azpiri H., González-Sosa E., Hernández-Sandoval L., Malda-Barrera G. and Martínez-Díaz M. 2011. Fog interception by ball moss (Tillandsia recurvata). Hydrology and Earth System Sciences 15:2509-2518.

Montaña C., Dirzo R. and Flores A. 1997. Structural parasitism of an epiphytic bromeliad upon Cercidium praecox in an intertropical semiarid ecosystem. Biotropica 29:517-521.

Olson M.E. 2005. Wood, bark, and pith anatomy in Pittocaulon ( Senecio, Asteraceae): water storage and systematics. Journal of the Torrey Botanical Society 132:173-186.

Páez-Gerardo L.E., Aguilar-Rodríguez S., Terrazas T., Huidobro-Salas M.E. and Aguirre-León E. 2005. 
Received:

Jamuary 29th, 2015

Accepted:

Auğust 31st, 2015
Cambios anatómicos en la corteza de Parkinsonia praecox (Ruiz et Pavón) Hawkins causados por la epifita Tillandsia recurvada L. (Bromeliaceae). Boletín de la Sociedad Botánica de México 77:59-64.

Poltz K. and Zotz G. 2011. Vascular epiphytes on isolated pasture trees along a rainfall gradient in the lowlands of Panama. Biotropica 43:165-172.

Roth I. 1981. Structural Patterns of Tropical Barks. Encyclopaedia of Plant Anatomy. Gebruder Borntraeger, Berlin.

Ruinen J. 1953. Epiphytosis. A second view on epiphytism. Annales Bogorienses 1:101-157.

Ruzin S.E. 1999. Plant Microtechnique and Microscopy. Oxford University Press, New York.

Shain L. 1995. Stem defense against pathogens. In: Gartner B.L. Ed. Plant Stems: Physiology and Functional Morphology, 383-406, Academic Press, San Diego.

Smith L. and Downs J.R. 1977. Tillandsioideae (Bromeliaceae). Flora Neotropica Monograph No.14, Part 2. Hafner Publising Co., New York..

Soria N.F., Torres C. and Galetto L. 2014. Experimental evidence of an increased leaf production in Prosopis after removal of epiphytes (Tillandsia). Flora - Morphology, Distributionm Fuctional Ecology of Plants 209:580-586.

Trockenbrodt M. 1990. Survey and discussion of the terminology used in bark anatomy. IAWA Bulletin new series 11:141-166.

Türkowsky C.J. and López-Ocaña C. 1983. Estudio ecológico del tillandsial de Cajamarquilla, Lima. Zonas Aridas 3:5-24.

Vivanco M.J., Cosio E., Loyola-Vargas V.M. and Flores H.E. 2005. Mecanismos químicos de defensa en las plantas. Investigación y Ciencia 341:68-75.

Wagner K., Mendieta-Leiva G. and Zotz G. 2015. Host specificity in vascular epiphytes: a review of methodology, empirical evidence and potential mechanisms. AoB Plants 7: plu092.

Zucker W.V. 1983. Tannins: Does structure determine function? An ecological perspective. The American Naturalist 121:335-365. 